\title{
Efficiency of pendimethalin, ioxynil, and accase inhibitors in controlling weeds in direct seeding onion
}

\section{Eficiência de pendimethalin, ioxynil e inibidores da accase no controle de plantas daninhas em semeadura direta de cebola}

\author{
Marcelo PEZENTI ${ }^{1}$; Diogo Luiz FRUET ${ }^{2 *}$; Dieison OLESCOWICZ ${ }^{1}$; Cristiane WERNKE $^{1}$; \\ Naiara GUERRA ${ }^{3}$; Antonio Mendes de OLIVEIRA NETO ${ }^{2}$
}

\begin{abstract}
${ }^{1}$ Instituto Federal Catarinense Campus Rio do Sul (IFC Rio do Sul), Rio do Sul, SC, Brazil.
${ }^{2}$ Centro de Ciências Agroveterinárias da Universidade do Estado de Santa Catarina (CAV/UDESC). Lages, SC, Brazil.

${ }^{3}$ Universidade Federal de Santa Catarina Campus Curitibanos (UFSC Curitibanos), Curitibanos, SC, Brazil.
\end{abstract}

* Corresponding author: diogofruet17@gmail.com

Recebido em: 04-09-2020; Aceito em: 28-10-2020

\begin{abstract}
This study evaluates whether the initial application of pendimethalin can increase the efficiency of ioxynil and ACCase inhibitor treatments in controlling weeds in direct seeding onion. The experiment was carried out in a commercial field in Ituporanga city, Santa Catarina State, Brazil. The onion cultivar Bola Precoce was used. The experimental design was in randomized blocks, in a factorial scheme $(2 \times 3)+1$, with four replications. Treatments consisted of pendimethalin application in the initial stage $\left(0\right.$ or $\left.600 \mathrm{~g} \mathrm{ha}^{-1}\right)$, three treatments based on ioxynil and ACCase inhibitors, sprayed at postemergence (ioxynil + clethodim (formulated as Select ${ }^{\circledR}$ ); ioxynil + fluazifop; and ioxynil + clethodim (formulated as Poquer $\left.{ }^{\circledR}\right)$ ), and a weeded control. Pendimethalin was sprayed immediately after onion crop establishment, and postemergence treatments were sprayed when the onion had 3 and 4 leaves (two sequential applications). The following were evaluated: control of Lolium multiflorum, Coronopus didymus, and Galinsoga parviflora, plant stand, bulb diameter, bulb weight, and total bulb yield. All treatments reached $100 \%$ control of $L$. multiflorum. All treatments were ineffective in controlling $C$. didymus and $G$. parviflora; however, the control of these weeds increased after pendimethalin application. The chemical treatments tested did not negatively influence any of the studied onion crop variables. There was a significant difference only for pendimethalin application in the initial stage, which significantly favored the variables under study. Pendimethalin application in the initial onion stage improved weed control and helped in maintaining bulb yield in direct seeding onion.
\end{abstract}

Additional keywords: Allium cepa, bulb yield, chemical control of weeds.

\section{Resumo}

O objetivo desta pesquisa foi avaliar se a aplicação inicial de pendimethalin pode aumentar a eficiência de tratamentos à base de ioxinil e inibidores de ACCase no controle de plantas daninhas em cebola de semeadura direta. O ensaio foi realizado em área comercial localizada em Ituporanga, SC. A cultivar Bola Precoce foi cultivada em sistema de semeadura direta. $O$ delineamento experimental foi em blocos casualizados, organizados em esquema fatorial $(2 \times 3)+1$, com quatro repetições. A interação entre a aplicação de pendimethalin na fase inicial $(0$ ou 600 $\mathrm{g}$ ha-1) com três tratamentos à base de ioxinil e inibidores de ACCase pulverizados em pós-emergência (ioxinil + cletodim (formulado como Select®), ioxinil + fluazifop e ioxinil + clethodim (formulado como Poquer $\left.{ }^{\circledR}\right)$ ). $O$ pendimethalin foi pulverizado imediatamente após o estabelecimento da cebola e os tratamentos pós-emergência foram pulverizados quando a cebola tinha 3 e 4 folhas (duas aplicações sequenciais). Avaliou-se o controle de Lolium multiflorum, Coronopus didymus e Galinsoga parviflora, estande, diâmetro do bulbo, peso do bulbo e produção total de bulbos. Todos os tratamentos alcançaram $100 \%$ de controle de L. multiflorum. Para C. didymus e G. parviflora, todos os tratamentos testados foram ineficientes no controle, porém, foi aumentado nos tratamentos a partir da aplicação de pendimethalin. Os tratamentos químicos testados não influenciaram negativamente nenhuma das variáveis estudadas da cultura da cebola, foi observada diferença significativa apenas para a aplicação de pendimethalin na fase inicial, o que favoreceu significativamente essas variáveis. A aplicação do pendimethalin na fase inicial da cebola contribuiu para o melhor controle de plantas daninhas e para a manutenção da produtividade de bulbos em cebola de semeadura direta.

Palavras-chave adicionais: Allium cepa, controle químico de plantas daninhas, produção de bulbos.

Introduction

Onion (Allium cepa) is the third vegetable in economic importance and in quantity produced in Brazil (Weingartner et al. 2018). The south region of the country is the largest producer of onion, with 803,703 $t$ (IBGE, 2018), accounting for $41 \%$ of the planted area in Brazil (Hortifruti Brasil, 2019). Santa Catarina State stands out as the largest national producer, with an area of 18,960 ha, average yield of $25,586 \mathrm{~kg} \mathrm{ha}^{-1}$, and total 
production of $485,122 \mathrm{t}$ in the 2018/2019 harvest (EPAGRI/CEPA, 2019).

Weed problems affect direct seeding onion growing fields in the Alto Vale do Itajaí region. Although herbicides are available for this crop, most of them are selective for seedling-transplanted plots, with little availability of herbicides intended for use in direct seeding systems (AGROFIT, 2020). Seedling transplanting has been adopted for many years in the region and is the predominant model. However, for onion production, due to high production costs and shortage of labor in the region, this system has been replaced by the direct seeding system. One of the major current difficulties is that direct seeding onion is more sensitive to weed interference than transplanted onion (Costa, 2007).

Another critical point for onion direct seeding is that the sensitivity of this crop to herbicides correlates with its development stage. Young plants, with less than three leaves, suffer from weed interference; however, chemical control during this period causes high phytotoxicity. This injury reduces plant stand and, consequently, bulb yield (Cavalieri, 2011).

Thus, this study evaluates the selectivity of the initial application of pendimethalin and whether this application improves the efficiency of treatments with ioxynil and ACCase inhibitors applied in the postemergence (POST) of direct seeding onion.

\section{Material and methods}

The experiment was carried out in Ituporanga city, Santa Catarina State, Brazil $\left(27^{\circ} 23^{\prime} 39.84^{\prime \prime}\right.$ S latitude, $49^{\circ} 38^{\prime} 44.51 " \mathrm{~W}$ longitude, and altitude of $420 \mathrm{~m}$ ), from June to December 2017. According to the Köppen-Geiger classification, the climate is $\mathrm{Cfa}$ (humid subtropical). Average annual temperature is $19.1^{\circ} \mathrm{C}$, and average annual rainfall is $1,530 \mathrm{~mm}$ (Catoni et al., 2012). Soil chemical analysis showed a $\mathrm{pH}_{\text {(water) }}$ of 5.8; $\mathrm{H}+\mathrm{Al}=4.5 \mathrm{cmol}_{\mathrm{c} \mathrm{dm}}{ }^{-3} ; \mathrm{K}=294.0 \mathrm{mg} \mathrm{dm}^{-3}$;
$\mathrm{Ca}=8.0 \mathrm{cmol}_{\mathrm{c}} \mathrm{dm}^{-3} ; \quad \mathrm{Mg}=2.6 \mathrm{cmol}_{\mathrm{c}} \mathrm{dm}^{-3}$; $\mathrm{P}=19.5 \mathrm{mg} \mathrm{dm}^{-3}$; O.M. $=6.3 \%, 71.61 \%$ base saturation; and $380 \mathrm{~g} \mathrm{~kg}^{-1}$ of clay.

The onion cultivation system used in the experiment was direct seeding. The soil was prepared about 40 days prior to the experiment with subsoiler, being leveled with a harrow 3 days before sowing. Initial fertilization consisted of the application of $320 \mathrm{~kg} \mathrm{ha}^{-1}$ of 05-20-20 NPK fertilizer and $1.4 \mathrm{tha}^{-1}$ of limestone, with incorporation through a leveling harrow. Topdressing consisted of the applications, at 35 and 120 days after sowing (DAS), of 20 and $45 \mathrm{~kg} \mathrm{~N}^{-1}$, respectively, using urea as the nitrogen source. Harrow leveling was performed to improve the efficiency of the pneumatic seeder. The onion cultivar used was 'Bola Precoce'. The cultivar was sown at a spacing of $0.3 \mathrm{~m}$, with a plant population of 425 thousand plants ha ${ }^{-1}$.

The experiment was conducted in a randomized block design, with treatments arranged in a factorial scheme $(2 \times 3)+1$. We tested the combinations of the initial application of pendimethalin (0 or $600 \mathrm{~g} \mathrm{ha}^{-1}$ a.i. $)$

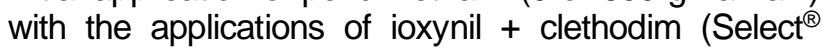
formulation $-125+96 \mathrm{~g} \mathrm{ha}^{-1}$ a.i.), ioxynil + fluazifop $\left(125+250 \mathrm{~g} \mathrm{ha}^{-1}\right.$ a.i. $)$, and ioxynil + clethodim (Poquer ${ }^{\circledR}$ formulation - $125+96 \mathrm{~g} \mathrm{ha}^{-1}$ a.i.) at postemergence (POST). ACCase-inhibiting herbicides were selected considering their register for the crop and their regional availability. Postemergence treatments were applied twice. In the first application, the onion had three leaves; in the second, it had four leaves. The additional treatment consisted of a weeded control. In total, seven treatments were evaluated, with four replications. The experimental units had a total area of $6 \mathrm{~m}^{2}(2 \times 3 \mathrm{~m})$.

Treatments were applied with a $\mathrm{CO}_{2}$-pressurized backpack sprayer equipped with a bar with four TT110015 flat spray nozzles spaced $0.5 \mathrm{~m}$ apart, with a constant pressure of $207 \mathrm{kPa}$ and a displacement rate of $3.6 \mathrm{~km} \mathrm{~h}^{-1}$. These operating conditions provided an application rate equivalent to $150 \mathrm{~L} \mathrm{ha}^{-1}$. The details of the applications are shown in Table 1.

Table 1 - Dates, plant stage and weather conditions at the time of application of treatments.

\begin{tabular}{lcll}
\hline & Pendimethalin application & \multicolumn{1}{c}{$1^{\text {st }}$ POST } & $2^{\text {nd }}$ POST \\
\hline Date & $7 / 3 / 2017$ & $7 / 31 / 2017$ & $8 / 21 / 2017$ \\
Time & $17 \mathrm{~h} 00$ & $17 \mathrm{~h} 15$ & $17 \mathrm{~h} 00$ \\
Stage of onion & 1 leaf & 3 leaves & 4 leaves \\
Weed & Not emerged & 8 leaves or 2 tillers & 4 to 6 leaves \\
Temperature & $20^{\circ} \mathrm{C}$ & $22{ }^{\circ} \mathrm{C}$ & $16.2^{\circ} \mathrm{C}$ \\
Relative humidity & $55 \%$ & $63 \%$ & $57 \%$ \\
Wind & $1.0 \mathrm{~km} \mathrm{~h}^{-1}$ & $0.4 \mathrm{~km} \mathrm{~h}^{-1}$ & $0.5 \mathrm{~km} \mathrm{~h}^{-1}$ \\
Phenological stage $^{*}$ & $\mathrm{C}$ & $\mathrm{D}$ & $\mathrm{E}$
\end{tabular}

POST - postemergence; *According to scale adapted by Wordell Filho (2006). C-whip, D-3 true leaves, E-4 true leaves.

For pendimethalin application, the plants were visually assessed prior to the first postemergence application. Subsequent control assessments were performed at zero, 15, and 30 days after the second postemergence application (DASA). The evaluated species were: ryegrass (Lolium multiflorum), swinecress
(Coronopus didymus), and smallflower (Galinsoga parviflora). The assessments consisted of assigning scores ranging from 0 to $100 \%$, with zero representing the absence of control and 100 representing plant death.

Harvesting was done on November 9, 2017, in 
one meter of two central rows $\left(0.6 \mathrm{~m}^{2}\right)$. After harvesting, the bulbs were cured for 2 weeks. Subsequently, the following were evaluated: plant stand (throughout two meters), average bulb diameter (measured in 10 bulbs per plot), average bulb weight (ratio between the mass and the number of bulbs harvested), total bulb yield (expressed in $\mathrm{t} \mathrm{ha}^{-1}$ ). The bulbs were not classified due to the occurrence of Iris yellow spot virus (IYSV), which affected their growth.

Analysis of variance was performed and the degrees of freedom of the interaction were unfolded for all the evaluated characteristics, even when the F Test was not significant. The means were compared using the Tukey test. The mean of the control without herbicide was compared with those of the herbicide treat- ments by the Dunnett test. All analyses were performed at a $5 \%$ significance $(p<0.05)$.

\section{Results and discussion}

Pendimethalin application during onion establishment in direct seeding system improved weed control (Table 2). The assessment conducted before the first POST application showed a general control of $49 \%$, being superior to the control without pendimethalin. However, it is noteworthy that this level of control is unsatisfactory and was lower than that of the weeded control. The initial control of weeds, before the plant emits the second leaf, is fundamental to avoid their interference (Dunan et al., 1996).

Table 2 - Evaluation of general weed control on the day of the first post-emergence application.

\begin{tabular}{lc}
\hline Pendimethalin & General control (\%) \\
\hline $0 \mathrm{~g} \mathrm{ha}^{-1}$ & $0 \mathrm{~b}^{*}$ \\
$600 \mathrm{~g} \mathrm{ha}^{-1}$ & $49 \mathrm{a}^{*}$ \\
Weeded control & 100 \\
\hline CV $(\%)$ & 29,11 \\
\hline
\end{tabular}

Means followed by the same letter do not differ by Tukey's test ( $p>0.05) .{ }^{*}$ differs significantly from the weeded control by Dunnett's test $(p<0.05)$.

The residual activity of an herbicide is mainly a function of soil persistence and mobility. Herbicides applied to the soil surface are often lost, especially if there is lack of moisture after application (Silva et al., 2007). Losses due to photodegradation can also occur. Other factors that may interfere with herbicide activity are volatilization, accentuated by increased soil temperature; chemical and biological degradation; and sorption. These are the main processes that eliminate herbicides from the soil (Monqueiro et al., 2012).

In this study, organic matter content was $6.3 \%$, a high value in comparison to the regional reality. Increasing the pendimethalin dose in this case could improve weed control, as well as prolong the residual period. On the other hand, an increase in the dose could lead to a high phytotoxicity of onion plants and thus the herbicide would not be selective for the crop. When using pendimethalin in the pre-emergence of castor bean, Silva et al. (2012) reported that the increase in the pendimethalin dose affected shoot and root dry matter; nonetheless, an increase in organic matter increased herbicide sorption into the soil, which mitigated its phytotoxic effect.

The tolerance of onion to herbicides under direct seeding depends on the cultivar, phenological stage, and herbicide. When studying the herbicide flumioxazin, Melo et al. (2019) observed that phytotoxicity varied as a function of the onion cultivar and the environment. Regarding the phenological stage, the authors observed that as the onion develops and the leaf wax increased, the phytotoxicity caused by flumioxazin decreased.

Table 3 shows the results of the efficiency of treatments in controlling ryegrass ( $L$. multiflorum), swinecress (C. didymus), and smallflower ( $G$. parviflora). For ryegrass, treatments with the herbicide clethodim, regardless of formulation, showed superior control to treatments with fluazifop at 0 and 15 DASA. These results corroborate the study by Cesarin et al. (2013), who indicated that clethodim formulations were highly efficient in controlling different species of the Poaceae family. However, in the last evaluation, performed at 30 DASA, all treatments provided total control of ryegrass.

In general, ryegrass has a greater capacity for interference than small-sized crops with reduced leaf area for radiation interception, such as onions and garlic (Soares et al., 2003). Two characteristics contribute to put crops at an advantage over weeds: tolerance (ability to maintain yield) and suppression (ability to reduce weed growth) (Carvalho et al., 2011). Onion does not have either a good tolerance or a good suppression, thus being the crop with the largest yield losses when subjected to coexistence with weeds. This shows the need for controlling ryegrass at the beginning of onion development, considering its very slow initial growth and low competitive ability.

Acetyl-CoA carboxylase (ACCase)-inhibiting herbicides are recommended for control of Poaceae species. Within this mechanism of action, aryloxyphenoxypropanoates (FOPs) (e.g., fluazifop) and cyclohexanediones (DIMs) (e.g., clethodim) are widely used because they are selective in non-Poaceae postemergence applications (Kukorelli et al., 2013).

The enzyme ACCase, target of these herbicides, can present itself in either a homodimeric or heterodimeric form. Magnoliopsida species have heterodimeric forms in plastids and homodimeric forms in cytosol, while Poaceae species present homodimeric forms in both plastids and cytosol. ACCase-inhibiting 
herbicides act only on the homodimeric form present in plastids, preventing the synthesis of fatty acids in grasses. These herbicides do not act on the heterodimeric form present in Magnoliopsida (Carvalho,
2013). This characteristic explains the high efficiency of the treatments on ryegrass and their selectivity for onion.

Table 3 - Evaluation of percentage of ryegrass (L. multiflorum), swinecress (C. didymus) and smallflower (G. parviflora) in the evaluations of 0,15 and 30 days after the second post-emergence application (DASA).

\begin{tabular}{|c|c|c|c|c|c|c|}
\hline \multicolumn{7}{|c|}{ Ryegrass (\% of control) } \\
\hline \multirow{3}{*}{ POST } & \multicolumn{2}{|c|}{0 DASA } & \multicolumn{2}{|c|}{15 DASA } & \multicolumn{2}{|c|}{30 DASA } \\
\hline & \multicolumn{2}{|c|}{ Pendimethalin } & \multicolumn{2}{|c|}{ Pendimethalin } & \multicolumn{2}{|c|}{ Pendimethalin } \\
\hline & $0 \mathrm{~g} \mathrm{ha}^{-1}$ & $600 \mathrm{~g} \mathrm{ha}^{-1}$ & $0 \mathrm{~g} \mathrm{ha}^{-1}$ & $600 \mathrm{~g} \mathrm{ha}^{-1}$ & $0 \mathrm{~g} \mathrm{ha}^{-1}$ & $600 \mathrm{~g} \mathrm{ha}^{-1}$ \\
\hline $\mathrm{P} 1$ & $95 \mathrm{aA}$ & 98 aA & $100 \mathrm{aA}$ & $100 \mathrm{aA}$ & 100 & 100 \\
\hline P2 & $92 \mathrm{aA}^{*}$ & $85 b B^{*}$ & $99 \mathrm{aA}$ & $98 \mathrm{bA}^{*}$ & 100 & 100 \\
\hline P3 & $94 \mathrm{aA}$ & $97 \mathrm{aA}$ & $100 \mathrm{aA}$ & $100 \mathrm{aA}$ & 100 & 100 \\
\hline Weeded control & \multicolumn{2}{|c|}{100} & \multicolumn{2}{|c|}{100} & \multicolumn{2}{|c|}{100} \\
\hline CV (\%) & \multicolumn{2}{|c|}{4,27} & \multicolumn{2}{|c|}{0,93} & \multicolumn{2}{|c|}{-} \\
\hline \multicolumn{7}{|c|}{ Swinecress (\% of control) } \\
\hline \multirow{3}{*}{ POST } & \multicolumn{2}{|c|}{0 DASA } & \multicolumn{2}{|c|}{15 DASA } & \multicolumn{2}{|c|}{30 DASA } \\
\hline & \multicolumn{2}{|c|}{ Pendimethalin } & \multicolumn{2}{|c|}{ Pendimethalin } & \multicolumn{2}{|c|}{ Pendimethalin } \\
\hline & $0 \mathrm{~g} \mathrm{ha}^{-1}$ & $600 \mathrm{~g} \mathrm{ha}^{-1}$ & $0 \mathrm{~g} \mathrm{ha}^{-1}$ & $600 \mathrm{~g} \mathrm{ha}^{-1}$ & $0 \mathrm{~g} \mathrm{ha}^{-1}$ & $600 \mathrm{~g} \mathrm{ha}^{-1}$ \\
\hline $\mathrm{P} 1$ & $21 \mathrm{aB}^{*}$ & $77 \mathrm{aA}^{*}$ & $41 \mathrm{bB}^{*}$ & $77 \mathrm{aA}^{*}$ & $18 \mathrm{aB}^{\star}$ & $66 \mathrm{aA}^{*}$ \\
\hline P2 & $23 \mathrm{aB}^{*}$ & $71 \mathrm{aA}^{*}$ & $64 \mathrm{aB}^{*}$ & $86 \mathrm{aA}$ & $20 \mathrm{aB}^{*}$ & $51 \mathrm{aA}^{*}$ \\
\hline P3 & $36 \mathrm{aB}^{*}$ & $78 \mathrm{aA}^{*}$ & $65 \mathrm{aB}^{*}$ & $87 \mathrm{aA}$ & $21 \mathrm{aB}^{*}$ & $68 \mathrm{aA}^{*}$ \\
\hline Weeded control & \multicolumn{2}{|c|}{100} & \multicolumn{2}{|c|}{100} & \multicolumn{2}{|c|}{100} \\
\hline CV (\%) & \multicolumn{2}{|c|}{15,16} & \multicolumn{2}{|c|}{13,29} & \multicolumn{2}{|c|}{24,75} \\
\hline \multicolumn{7}{|c|}{ Smallflower (\% of control) } \\
\hline & \multicolumn{2}{|c|}{0 DASA } & \multicolumn{2}{|c|}{15 DASA } & \multicolumn{2}{|c|}{30 DASA } \\
\hline POST & Penc & thalin & Pendi & thalin & Penc & ethalin \\
\hline & $0 \mathrm{~g} \mathrm{ha}^{-1}$ & $600 \mathrm{~g} \mathrm{ha}^{-1}$ & $0 \mathrm{~g} \mathrm{ha}^{-1}$ & $600 \mathrm{~g} \mathrm{ha}^{-1}$ & $0 \mathrm{~g} \mathrm{ha}^{-1}$ & $600 \mathrm{~g} \mathrm{ha}^{-1}$ \\
\hline $\mathrm{P} 1$ & $38 \mathrm{aB}^{*}$ & $73 a^{*}$ & $69 \mathrm{aB}^{*}$ & $80 \mathrm{bA}^{*}$ & $29 \mathrm{aB}^{\star}$ & $71 a A^{*}$ \\
\hline P2 & $36 \mathrm{aB}^{*}$ & $75 \mathrm{aA}^{*}$ & $73 \mathrm{aB}^{*}$ & $85 \mathrm{bA}^{*}$ & $26 \mathrm{aB}^{*}$ & $59 \mathrm{aA}^{*}$ \\
\hline P3 & $36 \mathrm{aB}^{*}$ & $76 \mathrm{aA}^{*}$ & $71 \mathrm{aB}^{*}$ & $91 \mathrm{aA}^{*}$ & $26 \mathrm{aB}^{*}$ & $71 \mathrm{aA}^{*}$ \\
\hline Weeded control & & & & & & \\
\hline CV (\%) & & & & & & \\
\hline
\end{tabular}

P1 = ioxynil + clethodim (Select formulation) $\left(125+96 \mathrm{~g} \mathrm{ha}^{-1} \mathrm{ia}\right), \mathrm{P} 2=$ ioxynil + fluazifop $(125+250 \mathrm{~g}$ ha-1 ia) and P3 = ioxynil + + clethodim (Poquer formulation) $\left(125+96 \mathrm{~g} \mathrm{ha}^{-1}\right)$.

Averages followed by the same lower case letter in the column (POST) and upper case line (PRE) do not differ by Tukey's test $(p>0.05) .\left(^{*}\right)$ differs significantly from the weed control by Dunnett's test $(p<0.05)$.

The treatments under study were inefficient in controlling swinecress, regardless of assessment. However, the treatments that received pendimethalin significantly improved swinecress control during crop establishment. The level of control provided by postemergence treatments was similar. Swinecress is considered a ruderal plant; however, it shows rapid germination and short development cycle in onion crops (Soares et al., 2003), which makes it a highly aggressive weed.

For smallflower, the control levels were better; notwithstanding, no treatment reached the final evaluation with satisfactory control $(\geq 80 \%)$. These results disagree with those reported by Ferreira et al. (2000), who obtained satisfactory small flower control in direct seeding onion with the application of ioxynil. However, the authors made three applications, with $125 \mathrm{~g} \mathrm{ha}^{-1}$ a.i at 19 DAS and $250 \mathrm{~g} \mathrm{ha}^{-1}$ a.i at 34 and 65 DAS.

In general, treatments with pendimethalin showed superior control in all assessment periods. This result agrees with Caratti et al. (2015), who evaluated the control of forage turnip with pendimethalin and obtained satisfactory results.

The interaction between the factors pendimethalin application and POST treatments, as well as the isolated factor POST treatments, showed no significant effect for the following variables: plant stand, bulb diameter, bulb weight, and total bulb yield (Table 4). The factor initial application of pendimethalin significantly influenced the variables bulb diameter, bulb weight, and total bulb yield. 
Table 4 - Evaluation of plant stand (PS - plants $\left.\mathrm{m}^{-1}\right)$, average bulb diameter (BD - mm), average bulb weight $(\mathrm{BW}-\mathrm{g})$ and total bulb productivity (TBP $\left.-\mathrm{t} \mathrm{ha}^{-1}\right)$.

\begin{tabular}{lcccc}
\hline Treatments & PS & BD & BW & TBP \\
\hline Pendimethalin & & & & \\
$0 \mathrm{~g} \mathrm{ha}^{-1}$ & $12.7 \mathrm{a}$ & $47.4 \mathrm{~b}$ & $88.6 \mathrm{~b}$ & $18.7 \mathrm{~b}$ \\
$600 \mathrm{~g} \mathrm{ha}^{-1}$ & $12.8 \mathrm{a}$ & $53.4 \mathrm{a}$ & $120.6 \mathrm{a}$ & $25.8 \mathrm{a}$ \\
\hline POST & & & & \\
P1 & $12.4 \mathrm{a}$ & $49.7 \mathrm{a}$ & $104.4 \mathrm{a}$ & $20.9 \mathrm{a}$ \\
P2 & $12.7 \mathrm{a}$ & $50.9 \mathrm{a}$ & $98.5 \mathrm{a}$ & $20.9 \mathrm{a}$ \\
P3 & $13.1 \mathrm{a}$ & $50.7 \mathrm{a}$ & $110.9 \mathrm{a}$ & $24.8 \mathrm{a}$ \\
Weeded control & 12.4 & 51.9 & 116.5 & 23.9 \\
\hline CV $(\%)$ & 16.57 & 8.39 & 23.73 & 18.98
\end{tabular}

$\mathrm{P} 1=$ ioxynil + clethodim (Select formulation) $\left(125+96 \mathrm{~g} \mathrm{ha}^{-1} \mathrm{ia}\right), \mathrm{P} 2=$ ioxynil + fluazifop $\left(125+250 \mathrm{~g} \mathrm{ha}{ }^{-1} \mathrm{ia}\right)$ and $\mathrm{P} 3=$ ioxynil + + clethodim (Poquer formulation) $\left(125+96 \mathrm{~g} \mathrm{ha}^{-1}\right)$. Averages followed by the same lower case letter in the column (POST) and upper case line (PRE) do not differ by Tukey's test $(p>0.05) .\left(^{*}\right)$ differs significantly from the weed control by Dunnett's test ${ }^{*}$ $(\mathrm{p}<0.05)$.

Plant stand was not influenced by pendimethalin application during onion establishment (Table 4). Studies carried out by Purdue University (2017) showed a reduction in onion stand with the application of 1,600 $\mathrm{g}$ a.i. ha ${ }^{-1}$ pendimethalin on plants with less than two leaves.

Several factors influence the selectivity of the herbicide pendimethalin in onion crop. Oliveira Jr. (2011) state that in the germination period the seedling shoots are devoid of wax, having a very permeable tissue for herbicide absorption. During crop development, after its establishment, wax deposition on the leaves reduces herbicide absorption, being a determining factor for selectivity (Assis, 2018).

The fact that pendimethalin does not affect plant stand is extremely positive, demonstrating that application at this stage did not cause plant death.

The variables bulb diameter, average bulb weight, and total bulb yield improved significantly with the application of $600 \mathrm{~g} \mathrm{ha}^{-1}$ pendimethalin during onion establishment. This result indicates that the use of pendimethalin, besides improving the control of Magnoliopsida species, contributed to onion yield and production components. The herbicide is thus an alternative to improve weed control at the beginning of the onion cycle under direct seeding system.

\section{Conclusion}

Clethodim and fluazifop provided total control of ryegrass (C. multiflorum). None of the treatments provided satisfactory control of swinecress ( $C$. didymus) or smallflower (G. parviflora). Pendimethalin application during onion establishment suppressed the growth of $C$. didymus and $G$. parviflora. Treatments with pendimethalin were superior for production components and bulb yield. This herbicide showed selectivity for onion crop and helped in maintaining yield.

\section{References}

AGROFIT (2020). Sistemas de agrotóxicos fitossanitários.

http://agrofit.agricultura.gov.br/agrofit_cons/principal_a grofit_cons <Acesso em 27/05/2020>

Assis ACLP (2018) Absorção foliar como mecanismo de tolerância da cebola ao flumioxazin aplicado nos estádios iniciais. 43 f. (Dissertação Mestrado) Universidade Federal de Viçosa, Rio Paranaíba, Brasil.

Caratti FC, Rosa TD, Silveira LP, Bonow JF, Rodrigues DB (2015) Desempenho de herbicidas pré-emergentes no controle de capim-arroz e nabo na cultura da soja. Enciclopédia Biosfera 11(22):867-874.

Carvalho LB (2013) Herbicidas. Leonardo Bianco de Carvalho, Lages, Brasil. $72 \mathrm{p}$.

Carvalho FP, Santos JB, Cury JP, Silva DV, Braga RR, Byrro ECM (2011) Alocação de matéria seca e capacidade competitiva de cultivares de milho com plantas daninhas. Planta Daninha 29(2):373-382.

Catoni JM, Neves L, Araujo JC, Oliveira EC, Haveroth R, Eli K, Fernandes E (2012) Balanço Hídrico e Classificação Climática para o Município de Ituporanga - SC. Anais XVII Congresso Brasileiro de Meteorologia. Gramado - RS.

Cavalieri SD, (2011) Árvore do conhecimento: Cebola. Agência Embrapa de informações tecnológicas. https://www.agencia.cnptia.embrapa.br/gestor/cebola/a rvore/CONT000gn0iyu2a02wx5ok0liq1 mq7mr143w.ht mkAcesso em 19 Ago 2019.

Cesarin AE, Martins JF, Giancotti PRF, Nepumuceno MP, Alves PLCA (2013) Eficácia de herbicidas no controle pós-emergente de Sisyrinchium micranthum Cav. e Agrostis sp. Revista Brasileira de Herbicidas 12(3):296. 
Costa NL (2007) Produtividade da beterraba e rúcula em função da época de plantio em monocultivo e consórcio. Horticultura Brasileira 25(4):577-581.

Dunan CM, Westra P, Moore F, Chapman P (1996) Modelling the effect of duration of weed competition, weed density and weed competitiveness on seeded, irrigated onion. Weed Research 36(3):259-269.

EPAGRI/CEPA (2019) Números da agropecuária catarinense 2019: Cebola https://cepa.epagri.sc.gov.br/index.php/produtos/acom panhamento-de-safras/<Acesso em: 10 nov. 2019>

Ferreira LR, Durigan JC, Churata-masca MGC, Ferreira FA, Silva AA. (2000) Seletividade e eficácia da aplicação sequencial de oxyfluorfen e de ioxynil-octanoato, em semeadura direta de cebola. Planta Daninha 18(1):39-50.

HORTIFRUTI BRASIL, (2019). Perspectivas HF 2019. https://www.hfbrasil.org.br/br/revista/acessar/completo/ anuario-2018-2019.aspx <Acesso em: 10 Nov. 2019>

IBGE (2018) Levantamento Sistemático da Produção Agrícola: Cebola. https://sidra.ibge.gov.br/tabela/1618\#resultado Acesso em: <05 jan. 2018>

Kukorelli G, Reisinger P, Pinke G (2013) ACCase inhibitor herbicides - selectivity, weed resistance and fitness cost: a review. International Journal of Pest Management 59(3):165-173.

Melo CAD, Barbosa AR, Dias RC, Silva GS, Reis MR (2019) Effectiveness of reduced doses of flumioxazin herbicide at weed control in direct sow onions. Revista Colombiana de Ciências Hortícolas 13(1):71-80.
Monqueiro PA, Sabbag R, Orzari I, Hijano N, Galvani Filho M, Dallacosta V, Krolikowski V, Hirata AC (2012) Lixiviação de saflufenacil e residual após períodos de seca. Planta Daninha 30(2):415-423.

Oliveira Jr RS et al. (2011). Biologia e Manejo de Plantas Daninhas. Ominipax, Curitiba. 215-216.

PURDUE UNIVERSITY (comp.). (2017) Midwest vegetable production guide for commercial growers 2017. Midwest Vegetable Production Guide For Commercial Growers 1(1):1-234. https://www.plantgrower.org/uploads/6/5/5/4/65545169 101_mwvegguide_2017.pdf. <Acesso em: 01 abr. 2020>

Silva AA, Silva JF (2007). Tópicos em manejo de plantas daninhas 83-147.

Silva KC, Silva VNB, Sofiatti V, Zonta JH, Lima RLS, Silva H (2012) Tolerância de mamoneira ao herbicida pendimethalin em solos com diferentes capacidades de adsorção. Revista Brasileira de Engenharia Agrícola e Ambiental 16(12):1298-1304.

Soares DJ, Pitelli RA, Braz LT, Gravena R, Toledo R e.B (2003) Períodos de interferência das plantas daninhas na cultura de cebola (Allium cepa) transplantada. Planta Daninha 21(3):387-396.

Weingartner, S, Gatiboni, LC Dall'orsoletta, D J, Kurtz, C, Mussi, M. (2018) Rendimento de cebola em função da dose e do modo de aplicação de fósforo. Revista de Ciências Agroveterinárias 17(1):23-29.

Wordell Fllho JÁ, Rowe E, Gonçalves PAS, (2006) Manejo fitossanitário na cultura da cebola. Epagri 1:226. 